\title{
Leading with Emotional Intelligence: How Leaders in a Diverse-Based Urban College in New York Successfully Responded to the COVID-19 Crisis of 2020
}

\author{
Michael Anibal Altamirano, Ph.D. ${ }^{1}$ \\ Carlos E. Rios-Collazo, Ph.D. ${ }^{2}$
}

\begin{abstract}
Strategically inclined organizations recognize the role of emergency management in their plans to address "worst case scenarios". The world has been impacted with unprecedented challenges permeating all kinds of civil structures. The COVID-19 disease, a simple micro-organic form of life, has destroyed global markets and people. In the United States, approximately 881,000 Americans have lost their jobs in the month of April 2020 alone (USDL, 2020). In terms of American education, the higher learning community has been forced to spin on its axis when public health measures have forced traditional colleges and universities to suspend residential learning, faculty staff have been laid-off and/or furloughed, and institutions continue to see their doors closed to their residential student body (Rosowsky, 2020). In response to the previous, this article describes how a small educational institution serving a diverse group of urban, under-represented, and international adult students managed to successfully operate amid the challenges of the COVID-19 pandemic. The discussion provides insights on leadership initiatives that rely on emotional intelligence to maintain student retention, enrollment, and motivation, and to protect its human capital. The findings seek to provide new and enlightened perspectives that may aid challenged leaders among comparable institutions to better formulate operational responses that will help them to successfully address current and future operational crises.
\end{abstract}

Key words: Leadership, Emotional Intelligence, Higher Education, Strategic Management, COVID-19

\footnotetext{
${ }^{1}$ Professor, King Graduate School, Monroe College, NY, USA, e-mail: maltamirano@monroecollege.edu

${ }^{2}$ Professor, King Graduate School, Monroe College, NY, USA, e-mail: crioscollazo@ monroecollege.edu
} 


\section{Introduction}

As expected, the year 2020 started much like any other year, with airs of hope and optimism driving the idea of a new year that promised better outcomes than the last one. For universities in the United States, January is normally the starting point of a new semester. And for the urban institution selected for this article-referred to hereinafter under the pseudonym of Urban Diverse College (UDC) - it was business as usual, too. UDC, an ethnically diverse and multicultural institution headquartered in Bronx, NY, serves a population predominated by first-generation American students, under-represented minorities, and international representatives of essentially every country around the world. And in the case of UDC, the institution is well known for its retention rate yielding to favorable ranks for its diversity and high-quality standards of education.

In January of 2020, the news in the United States began reporting that an unknown virus involving cases that were first observed in China was severely affecting public health (Munster, Koopmans, van Doremalen, van Riel, \& de Wit, 2020). Most people in the U.S. paid little attention to it because the severity was unknown, and perhaps its association to cases in China did not seem as a matter affecting their immediate reality. However, in two months, the reporting of the corona virus became more persistent. And on February 11, the World Health Organization (WHO) renamed the virus, referred to as "Corona", COVID-19; a mortal acronym for Corona Virus Disease of 2019 (World Health Organization, 2020). Then by March 1, the state of New York reported its first case of COVID-19, and the events that followed led to unprecedented hardships (Goldstein \& McKinley, 2020). As a result, on March 9 the governor of New York, Andrew Cuomo, reported 142 confirmed COVID-19 cases in the state (New York State, 2020). On March 10, the president of UDC sent out an email to the entire UDC community assuring everyone the organization was monitoring reports from the Governor of New York and the WHO, and that for the time being the college would remain open. But on March 11, after Governor Cuomo announced 216 confirmed cases of COVID-19 (2020), the president of UDC sent out a mass email to the college community informing everyone that the college was closing its doors out of an abundance of caution. The email went on to say the college would suspend all courses until March 14 while the college prepared for the transition. This same course of action was followed by virtually every learning institution pivoting on a residential model of education. Sadly, this reality appears to be reshaping the future of the American higher education sector. As Rosowsky (2020) suggested, realities 
of the present external environment are shaping future strategic models of a post-COVID-19 backdrop of higher education.

In light of the above, the goal driving this discussion was to examine leadership responses supporting UDC's strategic continuity of operations to counter the COVID-19 pandemic impact that has essentially locked down the American education system (Cowen, 2020). The higher education sector has never dealt with such type of crisis where institutions worldwide have closed their doors indefinitely (Cowen, 2020; Fernandes, 2020). Apart from this universal issue, some universities were better prepared than others (Gudi \& Tiwari, 2020). Therefore, while this analysis is not comparative in nature, it is nevertheless designed to explore how the selected institution found itself ready and able to manage the COVID-19 dilemma. Consequently, the discussion focuses on the role of emotional intelligence in the leadership skills that UDC decision makers applied to enable the organization to preserve its instructional offerings, student retention, projected enrollment, and motivation while protecting its human capital. Dan Goleman popularized the term Emotional Intelligence as the ability to understand one's own emotions to relate to others in positive or negative manners. In the current case of UDC, emotional intelligence plays a key role in managing stress factors within its community, as suggested by Batool (2013).

\section{Strategic Management}

Without the need to presume clairvoyant virtues, a reasonably competent academic administrator neither envisioned the need to prepare his or her institution for the effects of a COVID-19-type of public challenge nor the global impact that followed (Boin, 2019). The organizational structure of leading institutions like UDC is as complex as any other university structure may be. The constituency of UDC is made up of faculty, students, staff, directors, and senior governance officials. UDC recently underwent reaccreditation where they performed an organization-wide self-study that coincided with strategic planning initiatives. The college developed various "what if" scenarios where it tested its capacity to respond to various emergencies. UDC determined that one of its most important core competencies was the ability to create a responsive and nurturing culture for its students. Specifically, UDC determined that no matter what incident could transpire, the most important and nonnegotiable factor needed to be student services and the deliverables that would continuously contribute to student success. 
Like most universities around the world, UDC uses a learning software that aides in organizing classroom activities for both instructors and students (Aljawarneh, 2019). The system UDC uses, like many other American institutions, is Blackboard ${ }^{\circledR}$. Blackboard is a computer-mediated distance learning (CMDL) platform that allows instructors to organize course activities such as weekly lecture outlines, learning resources, assignments, assessments, and report drop boxes (Blackboard, 2020). This CMDL empowers students to access their courses remotely regardless of their geographical separation from the instructor and the serving institution (Rios-Collazo, 2017).

From a strategic perspective, all instructors at UDC receive training on how to use the aforementioned CMDL. Some would consider the following events as serendipitous, but rather they reflect the positive fortune of a strategically prepared organization (Kesebi, 2019). At the start of the semester in January of 2020, UDC announced that they would be adopting a new version of Blackboard that was dramatically different from previous versions. UDC insisted that both online and live classroom instructors undergo mandatory training in order to continue serving students academically and without disruption. The new version of Blackboard was radically different from and more complicated than the previous version, but UDC's leadership explained that the newer version, while more difficult for instructors to learn, was easier for students to maneuver. This customer-first strategic model was expected to bear fruit in the months to follow.

Prior to January 2020, UDC restructured its student services initiatives to support its student population more efficiently. The restructuring bridged student services with academic outcomes by encouraging student-centered teaching techniques that placed the needs of UDC's students first because the urban, multicultural, and global population comes with learning barriers such as cultural, language, and financial, and other learning barriers (Altamirano, 2019). The graduate and undergraduate schools of UDC began to approach curriculum selection with students in mind, creating more supportive environments by encouraging instructors to respond to student emails within 24 hours and expediting the grading of assignments. There was a strong emphasis on evaluating students in meaningful and transparent ways through clear and measurable pedagogy and frequently updated individual grade reports found through individual courses using the school's CMDL. In addition, UDC offered learning forums for instructors focusing on learning student values and improving teaching delivery. As Table 1 illustrates below, UDC also offers several student support programs designed to assist emotional challenges or factors affecting the emotional preparedness of its student body. 
Table 1. Sample of UDC's Student Services and Support Programs

\begin{tabular}{|l|l|}
\hline Student Need & Programmatic Description \\
\hline Transportation & Free student transportation between Bronx and New Rochelle \\
\hline Technical Infrastructure & Library services extending campus to off-site database access \\
\hline Student Success Services & Individualized support, free tutoring, writing and research assistance \\
\hline Emotional Support & $\begin{array}{l}\text { Available on all campuses with added support on developing } \\
\text { students' career-oriented skills }\end{array}$ \\
\hline Experiential Transition & $\begin{array}{l}\text { Team of professionals assigned to closely track and support } \\
\text { academic progress and success of first-year students }\end{array}$ \\
\hline Wellness and Health & $\begin{array}{l}\text { Team of professionals from different disciplines dedicated to assist } \\
\text { students' health habits, lifestyle choices, and practices designed to } \\
\text { support and advance their physical, mental, and emotional wellbeing }\end{array}$ \\
\hline Proctored Services & \begin{tabular}{l} 
Supervised examination support services for students and applicants \\
\hline
\end{tabular}
\end{tabular}

In March 14, UDC successfully transferred into a $100 \%$ online mode that allowed its uninterrupted continuity of courses and services. This also includes the added flexibility of continuing 100\% instructor-based operations via telework. And while most resident students vacated their dormitories, those who were unable to do so (e.g. international exchange students), UDC provided safe dorm accommodations and food services. UDC also made arrangements to provide computers for those students who, for a variety of reasons, had no access to technology. Counselors and administrators were easily accessible via phone with little or no waiting time.

\section{Leadership and Emotional Intelligence}

In a rapidly evolving world, leaders and managers are required to apply a certain degree of emotional intelligence to cope with developing challenges in their environment (Iraj Soltani, 2014). Supporting the foregoing is Iraj et al.'s (2014) study involving a random sample of $(n=130)$ managers who have reportedly overcome organizational crises. The data collected through surveys revealed a high statistical correlation between emotional intelligence and crisis management. Specifically, these researchers reported results showing a path analysis determined, with a 0.58 coefficient, why emotional intelligence influenced crisis management capabilities among the participating managers (p. 422). Understanding the value of emotional intelligence in a leader's response to a crisis/emergency situation 
is imperative because emotional intelligence can play a significant role in the process (Suhaimi, Marzuki, \& Mustaffa, 2014). Of note too is the fact that, while emotional intelligence is not a remedy for all leadership challenges, it may act as a leadership enhancing agent that allows an experiential connection in unconventional interaction such as virtual interactive settings (Rios-Collazo, 2017).

The above appears to find alignment with UDC's responses to the puzzling COVID-19 pandemic challenge. Accompanied by a sound strategic guideline, organizational leaders at UDC began steady and deliberate guidance for all its constituents. The result of this effort was a cultural shift that placed greater emphasis on support of the student experience during the transition to a fully online educational and service platform. Specifically, the President of UDC led the way with daily telephone and email communications addressed to the entire UDC community. Senior executives at the institution ensured that business functioned as normal during these most difficult of times. Staff and faculty continued to operate from home via use of a CMDL platform that diversified their communication avenues with students and enhanced contact via video teleconference. These means empowered them to respond to students' needs affected by the emergent need to transition into a full-time online education model.

Because of the unprecedented nature of the COVID-19 pandemic, leading organizations throughout this crisis have been without standard operating procedures (Gates, 2020). Contrasting the foregoing, the President of UDC examined critical factors that needed attention as he moved forward with contingency plans. The critical factors that UDC's leadership identified were retention and enrollment of students, as well as the safety and wellness of the entire UDC community of faculty and staff.

After examining the critical factors leading to making the difficult decision of closing the college, leaders encountered several issues that threatened a smooth transition into a fully virtual operational platform. For example, a percentage of students did not have computers or access to internet service. UDC leaders made sure that students without computers were able to obtain one and be in a position to complete their semester's work. For students who could not obtain internet service, UDC managed to keep several buildings opened where students could go to campus and work in a supervised and socially distant environment that met federal, state, and locally adopted public health guidelines. The goal was to ensure that $100 \%$ of the student population had access to their course. There was also the issue of COVID-19 related trauma. UDC students received access to counseling and therapy, free of charge, as needed. Student counselors were available via phone to manage issues related to courses, academics, registration, tuition, and conflict resolution. Leaders also provided ongoing information on 
the COVID-19 pandemic and information on testing sites in the New York City and surrounding areas. The overall student response to these initiatives was overwhelmingly positive.

After the leaders of UDC addressed potential obstacles, they followed with a consistent communication campaign that played a key role in the successful guidance provided to the UDC community facing the evolving COVID-19 pandemic. Consistent communication is critical toward alleviating uncertainty in times of crisis (Sellnow, Sellnow, Helsel, Martin, \& Parker, 2018). The President of UDC implemented a weekly movement of emails and phone call messages with the goal of encouraging constituents through heartfelt motivational messages and information on developments concerning the community at large. Within the information, this UDC leader further included dates of several web seminars on various health and wellness topics including information on coping with the stress of living during the COVID-19 pandemic, classes on nutrition, meditation sessions, and exercise classes such as yoga and virtual Zumba. All these meet-up sessions served toward bringing students, staff, and faculty closer together during a time when people felt the distancing effect of adopted quarantine measures (DeShano Wakeman, 2020).

Under normal circumstances, the rigours of education are clear in regards to expectations. Educational pedagogy does not often account for outside factors such as emotional distress (Colvonen, Straus, Acheson, \& Gehrman, 2019). The needs of the urban, multicultural, and international students are as unique as their backgrounds (Lekwa, Reddy, Dudek, \& Hua, 2018). Showing sensitivy to these factors, the leaders of UDC set forth a directive that no student would fail a course as long as he or she completed all course requirements. They also directed all instructors to work with struggling students and accept late work in good faith if students were resolved to catch up and meet academic requirements. The previous led to other successful operations that empowered most students to benefit from this calibrated opportunity to complete their semester positively. However, there were a small percentage of students who, for various reasons, could not pass or dropped a course. Those who could not pass received a grade of "I" for incomplete and were assured that, if they completed their entire course requirements, the grade would change to a passing one.

Those with traditional values often consider initiatives as previously described controversial. Educational leaders with heightened emotional intelligence understand that these are not traditional times. Leading in times of this COVID-19 pandemic is without standard (Stoller, 2020). Business as usual is a directive for failure during these uncertain times, which require leaders to push forward 
beyond standard operating procedures and pave new roads of operational management that emphasize emotional intelligence toward constituents.

\section{Discussion and Recommendations}

The information treated in this article serves to remind everyone that it is impossible to prepare for uncertainty. The reality of COVID-19 is that it does not discriminate in its purposeful impact. Businesses in every industry, especially higher education, have and continue to experience economic distress, unwanted unemployment effects, and a hindered customer service capability (Parks, 2020). However, the idea of strategic management invites organizations to be prepared for times of crisis (Tokakis, Polychroniou, \& Boustras, 2019). But as in all cases, some organizations outperform others during times of impromptu distress and hardships.

Here, the focus of the article was neither comparative nor critical of any other institutions of higher learning. Instead, the preceding discussion and shared findings provided insights on identified successful practices espoused at a selected institution, which, as part of its accreditation process and a resilient interest among its leaders to find new ways to expand their support to a unique student population, empowered the institution to thrive amid the COVID-19 pandemic that has incredibly paralyzed the higher learning sector in the United States (Cowen, 2020).

\section{Acknowledgments}

The authors wish to thank UDC's leadership for allowing their access to the empirical data supporting this article. 


\section{References}

Aljawarneh, S. A. (2019, February). Reviewing and exploring innovative ubiquitous learning tools in higher education. Journal of Computing in Higher Education.http://csweb.cs.wfu.edu/ pauca/csc332/caspapers/context-aware-ubicomp-learning.pdf Altamirano, M. A. (2019, June). Leadership challenges of urban institutions of higher learning, which serve a predominantly diverse and multi-cultural student population. Journal of Education, Innovation, and Communication, 1(1).https://www.researchgate.net/profile/margarita_kefalaki/publication/335241283_2019_jeico m_volume_1_issue_1_june_2019/links/5d5ac385458515210251d153/2019-jeicom-volume-1issue-1-june-2019.pdf\#page $=43$

Batool, B. F. (2013). Emotional intelligence and effective leadership. Journal of business studies quarterly, 4(3), 84.

Blackboard. (2020). Blackboard Learning Technologies.https://www.blackboard.com/

Boin, A. (2019, January). The Transboundary Crisis: Why we are unprepared and the road ahead. Journal of Contingencies and Crisis Management, 27(1), 9499.https://onlinelibrary.wiley.com/doi/pdf/10.1111/1468-5973.12241

Colvonen, P. J., Straus, L. D., Acheson, D., \& Gehrman, P. (2019). A Review of the Relationship Between Emotional Learning and Memory, Sleep, and PTSD. Current Psychiatry Reports, 21(2).https://www.ncbi.nlm.nih.gov/pmc/articles/pmc6645393/

Cowen, T. (2020, May 11). Bloomberg. Retrieved from Bloomberg Opinion: https://www.bloomberg.com/opinion/articles/2020-05-11/what-colleges-must-do-to-survivethe-coronavirus-crisis

DeShano Wakeman, S. (2020, April). Staying Resilient in a Time of Crisis.http://www.apta.org/blogs/pttransforms/2020/4/14/stayingresilient/

Fernandes, N. (2020, March). Economic Effects of Coronavirus Outbreak (COVID-19) on the World Economy. SSRN.https://foroparalapazenelmediterraneo.es/wp-content/uploads/2020/03/ssrnid3557504.pdf.pdf

Gates, B. (2020, February). Responding to COVID 19: A Once in a Century Pandemic? New England Journal of Medicine.https://www.nejm.org/doi/full/10.1056/nejmp2003762 
Goldstein, J., \& McKinley, J. (2020, March). Coronavirus in N.Y.: Manhattan Woman Is First Confirmed Case in State. The New York Times.https://www.nytimes.com/2020/03/01/nyregion/new-york-coronvirus-confirmed.html

Goleman, D. (1996). Emotional intelligence: Why it can matter more than IQ. Bloomsbury Publishing.

Gudi, S. K., \& Tiwari, K. K. (2020, April). Preparedness and Lessons Learned from the Novel Coronavirus Disease. The International Journal of Occupational and Environmental Medicine, 11(2).https://www.theijoem.com/ijoem/index.php/ijoem/article/view/1977/1213

Kesebi, O. (2019, May). Disruption Ready: Building market resilience through adapted foresight, organizational agility, co-creative intelligence and employee engagement. OCAD University Open Research

Repository.http://openresearch.ocadu.ca/id/eprint/2707/1/kesebi_oktay_2019_mdes_sfi.pdf

Lekwa, A. J., Reddy, L. A., Dudek, C. M., \& Hua, A. N. (2018, November). Assessment of teaching to predict gains in student achievement in urban schools. School Psychology Quarterly.file:///c:/users/slice/downloads/mapgainscsas-ospqfinal.pdf

Munster, V. J., Koopmans, M., van Doremalen, N., van Riel, D., \& de Wit, E. (2020, February). A Novel Coronavirus Emerging in China $\hat{\mathrm{A}}$ - Key Questions for Impact Assessment. The New England Journal of Medicine.https://www.nejm.org/doi/full/10.1056/nejmp2000929

New York State. (2020, March). At Novel Coronavirus Briefing, Governor Cuomo Announces State Will Provide Alcohol-Based Hand Sanitizer to New Yorkers Free of Charge. Department of Health: https://www.governor.ny.gov/news/novel-coronavirus-briefing-governor-cuomoannounces-state-will-provide-alcohol-based-hand

Parks, V. (2020, April). The Critical Role of Social Capital During the COVID 19 Pandemic: Lessons from Disaster Research. Center for Population Studies: University of Mississippi.https://egrove.olemiss.edu/cgi/viewcontent.cgi?article=1001\&context=population_bri ef

Rios-Collazo, C. E. (2017). Leadership in a Virtual Learning Environment: A Case Study on the Emotional Intelligence Practices of Qualified Educators Advancing Success in the Private Education Sector. Winston-Salem: ProQuest.

Rosowsky, D. (2020, May 18). Forbes. Retrieved from Forbes Billionaires : https://www.forbes.com/sites/davidrosowsky/2020/05/18/the-furlough-dilemma-in-highereducation/\#7aa3b6921f75 
Sellnow, T. L., Sellnow, D. D., Helsel, E. M., Martin, J. M., \& Parker, J. S. (2018, January). Risk and crisis communication narratives in response to rapidly emerging diseases. Journal of Risk Research, 22(7), 897-908.https://www.tandfonline.com/doi/full/10.1080/13669877.2017.1422787

Soltani,I., Shahsavari, M., \& Moradi, M. (2014). The Impact of Emotional Intelligence on Crisis Management Capabilities Case Study: Small and Medium Enterprises in the Province of Isfahan. International Journal of Academic Research in Business and Social Sciences, 415-423.

Stoller, J. K. (2020, April). Reflections on leadership in the time of COVID 19. BMJ Journals.https://bmjleader.bmj.com/content/leader/early/2020/04/07/leader-2020-000244.full.pdf

Suhaimi, A. W., Mazurki, N. A., \& Mustaffa, C. S. (2014). The Relationship between Emotional Intelligence and Interpersonal Communication Skills in Disaster Management Context: A Proposed Framework. Procedia - Social and Behavioral Sciences, 110-114.

Tokakis, V., Polychroniou, P., \& Boustras, G. (2019, March). Crisis management in public administration: The three phases model for safety incidents. Safety Science, 113, 3743.https://fardapaper.ir/mohavaha/uploads/2019/02/fardapaper-crisis-management-in-publicadministration-the-three-phases-model-for-safety-incidents.pdf

USDL-20-0521. (2020, April 3). Bureau of Labor Statistics U.S. Department of Labor.https://www.bls.gov/news.release/pdf/empsit.pdf

World Health Organization. (2020). Naming the coronavirus disease (COVID-19) and the virus that causes it.https://www.who.int/emergencies/diseases/novel-coronavirus-2019/technicalguidance/naming-the-coronavirus-disease-(COVID-2019)-and-the-virus-that-causes-it 